ISSN 1392-3196 / e-ISSN 2335-8947

Zemdirbyste-Agriculture, vol. 106, No. 4 (2019), p. 367-376

DOI 10.13080/z-a.2019.106.047

\title{
The evaluation of disease resistance of flax genotypes in relation to environmental factors
}

\author{
Inga STAFECKA ${ }^{1,2}$, Dace GRAUDA ${ }^{3}$, Veneranda STRAMKALE ${ }^{1}$ \\ ${ }^{1}$ Institute of Agricultural Resources and Economics, Priekuli Research Centre \\ Zinatnes 2, Priekuli, Priekulu distr., Latvia \\ E-mail: inga.stafecka@arei.lv \\ ${ }^{2}$ Daugavpils University \\ Parades 1, Daugavpils, Latvia \\ ${ }^{3}$ University of Latvia, Institute of Biology \\ Miera 3, Salaspils, Latvia
}

\begin{abstract}
Fungal diseases are one of the limiting factors of flax (Linum usitatissimum L.) production in variable environmental conditions. The expansion of fungal diseases depends on the plant resistance, pathogen population's ability to overcome this resistance and plant growth conditions. This study is aimed to estimate the flax resistance to fungal diseases in relation to environmental factors under the field conditions and identify the most promising accessions for plant breeding. A total of 24 fibre flax genotypes of local origin were investigated. The flax genotypes with different resistance to the most common diseases were identified using the area under the disease progress curve (AUDPC) for plants and resistance index (RI): in the growing season with high humidity there were identified the genotypes that were more susceptible to wilt (caused by Fusarium oxysporum f. sp. lini), pasmo (caused by Septoria linicola) and anthracnose (caused by Colletotrichum lini), and in the growing season with drier conditions there were identified the genotypes that were more susceptible to stem break, browning of flax (caused by Polyspora lini), powdery mildew (caused by Oidium lini) and fusarium browning (caused by Fusarium spp.). The highest incidence of the causal agents Fusarium spp. and Colletotrichum lini on the flax seeds was identified in high humidity conditions. The most valuable flax genotypes S13/5-7/5-93, S64-17-93, T11-13/3-1-94 and L11-11/11-97 exhibited relatively high complex resistance to diseases and high yield compared to the standard cultivar 'Vega 2'. The genotype 'Rezeknes' exhibited higher resistance to the powdery mildew at the seedling stage and complete resistance at the adult plant stage compared to all accessions.
\end{abstract}

Key words: breeding, causal agents of diseases, Linum usitatissimum, susceptibility.

\section{Introduction}

Flax (Linum usitatissimum L.) is one of the oldest, multifunctional crops cultivated for the purpose of oil and fibre (Dunford, 2015; Gudmewad et al., 2016). It has a long history of cultivation in warm and cool temperate climate regions (Belonogova, Radulgina, 2007). The wide use of flax as a valuable raw material for industry dictates the necessity of developing new highly productive and resistant cultivars, and this requires a detailed knowledge of characteristics of its genetic resources (Rachinskaya et al., 2011). With climate change, the value of flax genetic resources for agriculture will increase and may put strong pressure on breeding programmes to adapt cultivars to different conditions at an accelerating rate. The availability of diverse germplasm, characterization data and evaluation data is of the greatest importance to realize the full potential of flax in agriculture (Nozkova et al., 2006).
In flax growing regions environmental conditions increase favour susceptibility to fungal infections, which could lead to epidemic progress. Flax diseases are mainly caused by fungi from the genus Fusarium, infection with which can lead to over $20 \%$ loss in the flax yield. The globally most widespread pathogen of flax is Fusarium oxysporum f. sp. lini (Wojtasik et al., 2015). However, every flax growing area has a problem with specific diseases of flax and other widespread, and harmful diseases are rust (caused by Melampsora lini), anthracnose (caused by Colletotrichum lini) and pasmo (caused by Mycosphaerella linicola or Septoria linicola), less common - powdery mildew (caused by Oidium lini), stem break and browning (caused by Polyspora lini) (Diederichsen et al., 2008; Jankauskienè, Gruzdevienè, 2008; Heller et al., 2015; Wang et al., 2018).

Please use the following format when citing the article:

Stafecka I., Grauda D., Stramkale V. 2019. The evaluation of disease resistance of flax genotypes in relation to environmental factors. Zemdirbyste-Agriculture, 106 (4): 367-376. DOI 10.13080/z-a.2019.106.047 
Flax seeds are susceptible to some important seed borne diseases under certain weather conditions (Muskett, 2008; Finch et al., 2014). The seeds are very hygroscopic, which makes them a good medium for the distribution of various fungi (Gruzdeviene et al., 2006). Flax seeds could be infected with the following disease-causing agents: Botrytis spp., Alternaria spp., Fusarium spp., Colletotrichum lini and Ascochyta linicola (Mankeviciene et al., 2011; Finch et al., 2014). The fungi pathogens may live even longer than the seeds they colonize. Flax seeds retain germinability for 18 to 24 months, whereas Botrytis cinerea, Colletotrichum lini and Polyspora lini survive for more than four years on the seeds (Agarwal, James, 1996).

The most commonly practised disease control method in agriculture is the use of resistant cultivars (Hall et al., 2016). In the world, the genetic determination of resistance to flax rust has been extensively studied, but for the other flax diseases, the progress could still be made. Currently, researchers are focusing on flax resistance to different diseases such as flax wilt, pasmo, anthracnose and powdery mildew in France (Penaud et al., 2017), Russia (Карпунин, 2015; Кудрявцева и др., 2016; Dmitriev et al., 2017), Canada (GalindoGonzalez, Deyholos, 2016), and China (You et al., 2017).

The progress of disease on plants is usually observed several times during pathogen epidemics. The extent of the disease is assessed at each observation using scales that are based on disease incidence, severity or a combination of both. To combine these repeated observations into a single value the area under the disease progress curve (AUDPC) for summarizing and comparing plant disease epidemics (Simko, Piepho,
2012). AUDPC was used as the objective measure for determining the level of horizontal (non-specific) resistance of a cultivar of the flax in the field. The AUDPC provides an opportunity to increase the effectiveness of the phytopathological assessment and to create cultivars with long-term resistance to the pathogen (Кудрявцева и др., 2016).

Plants and pathogens are continuously confronted with each other during evolution in a battle for growth and survival (Van Inghelandt et al., 2010). The ability of the pathogen to overcome the resistance makes breeding a constant process, which requires continuous improvement and quest for new sources of resistance (Loshakova, 1992). Therefore, improvements in the evaluation of genetic resources used for flax breeding with increased resistance to pathogens are of great importance, and this study is aimed to determine the resistance of flax to fungal diseases in relation to environmental factors under the field conditions and to assess and select the most promising accessions for breeding.

\section{Materials and methods}

The research was conducted at the Institute of Agricultural Resources and Economics, Priekuli Research Centre, Crop Research Department at Vilani, Latvia from 2014 to 2017 at flax seedling stage and from 2015 to 2017 at flax adult plant stage. Experimental material for the study consisted of 24 fibre flax (Linum usitatissimum L.) genotypes of the Latvian origin (Table 1) and 'Vega 2' (P25) of the standard cultivar of Lithuanian origin.

Table 1. Estimated fibre flax genotypes

\begin{tabular}{rlrlllll}
\hline No. & \multicolumn{1}{c}{ Genotype } & No. & \multicolumn{1}{c}{ Genotype } & No. & \multicolumn{1}{c}{ Genotype } & No. & \multicolumn{1}{c}{ Genotype } \\
\hline P1 & S13/5-7/5-93 & P7 & T25/5-33/12-8-94 & P13 & K47-17/11-6-95 & P19 & L26-47/1-97 \\
P2 & S32/4-8-93 & P8 & T29-36/10-5-94 & P14 & L2-14/6-97 & P20 & Altgauzen \\
P3 & S53/8-3-93 & P9 & T29-36/7-1-94 & P15 & L11-11/10-97 & P21 & Rezeknes \\
P4 & S64-17-93 & P10 & T31-40-94 & P16 & L11-11/11-97 & P22 & Rota 1 \\
P5 & T11-6/2-15-94 & P11 & T36-26/4-8-94 & P17 & L19-6/15-97 & P23 & Rota 2 \\
P6 & T11-13/3-1-94 & P12 & K47-17/11-1-95 & P18 & L23-26/3-97 & P24 & Ruda 1 \\
\hline
\end{tabular}

Plants were grown in standard block plots of $1 \mathrm{~m}^{2}$ with a distance between rows of $10 \mathrm{~cm}, 1700$ flax seeds per $1 \mathrm{~m}^{2}$ were sown by hand at the $1.5-2 \mathrm{~cm}$ depth in the field trial. Prior to sowing, germination tests were performed for all genotypes used. Seeds were sown within the first 10 days of May. Flax was grown in a Humic Gleyic Podzol (WRB, 2014). The main agrochemical parameters of the arable soil layer were as follows: humus content $-6.5 \%$, soil acidity $\left(\mathrm{pH}_{\mathrm{KCl}}\right)$ - 6.4-7.0, available $\mathrm{P}_{2} \mathrm{O}_{5}-130-145 \mathrm{mg} \mathrm{kg}^{-1}$ and available $\mathrm{K}_{2} \mathrm{O}-118-124^{2} \mathrm{mg} \mathrm{kg}^{-1}$ soil. Complex fertilizer NPK 16:16:16 $300 \mathrm{~kg} \mathrm{ha}^{-1}$ was applied after the first cultivation of soil. For plants' further development a surface fertilizer ammonium nitrate $30 \mathrm{~kg} \mathrm{ha}^{-1} \mathrm{~N}$ at firtree like stage (BBCH 19) was applied. Insecticide Fastac 50 (a.i. $50.0 \mathrm{~g} \mathrm{~L}^{-1}$ alpha-cypermethrin) $0.4 \mathrm{~L} \mathrm{ha}^{-1}$ was sprayed against flax flea beetles (Aphthona euphorbiae). The tractor-drawn sprayer "Pilmet 412" (Agromet Pilmet Sp. z o.o., Poland) was used for insecticide application. Fungicides for the control of flax diseases were not used at all. Plants were pulled manually at the stage of early yellow ripeness and then left on the ground for drying for 5-8 days. The seed vessels were removed by device "Eddi" (Latvia University of Life Sciences and Technologies). Seeds were cleaned with a sample cleaner MLN (Pfeuffer GmbH, Germany). The yield of seeds was weighed and then re-calculated to $100 \%$ purity and $12 \%$ humidity. Growth stages of flax were noted according to the BBCH scale (Nozkova et al., 2016)

Thirty marked flax plants from each genotype at the $1 \mathrm{~m}^{2}$ in the field trails were assessed every 7 days till flax pulling over the three vegetation periods under field conditions with natural infection. For the detection of causal agents on the flax seeds an analysis of four replicates of 100 seeds from each genotype was performed. The analyses of infected parts of the plants and seeds were done following the methodologies developed for phytopathological research (Лошакова и др., 2000; Grimault et al., 2014) at the laboratory the Institute of Biology of the University of Latvia.

For the determination of internal pathogen infection, the infected parts of the plants were disinfected 
with 50\% ethyl alcohol, then rinsed in distilled water and dried on a sterile filter paper. For the determination of internal fungal infection, the seeds were disinfected with $70 \%$ ethyl alcohol for $0.5 \mathrm{~min}$, then rinsed three times in distilled water and dried on a sterile filter paper. The infected parts of the plants or seeds were placed in Petri dishes (diameter $9 \mathrm{~cm}$ ) on the agar media (Agar-Agar Roth Art. No. 4508.1). After 6-9 days of incubation at a temperature of $24-26^{\circ} \mathrm{C}$, the Petri dishes were inspected for fungal contamination on the plants and seeds. The fungus was identified after the emergence of mycelium. The conidia shapes of the fungus were detected using a light microscope (Carl Zeiss Jena GmbH, Germany) by $640 \times$ magnification. The diseases were determined by morphological features using disease descriptors (Malone, Muskett, 1997; Лошакова и др., 2000; Damm et al., 2014).

Percentage of the affected plants was estimated and disease severity was recorded for the whole plant for each disease following a five-point scale: 0 - healthy, 1 - weakly affected, 2 - moderately affected, 3 - heavily affected, 4 - very heavily affected or dead plants. The disease incidence (I) and disease severity index (DSI) were determined. Incidence (\%) was calculated using the formula:

$$
\mathrm{I}=\frac{\mathrm{n}}{\mathrm{N}} \times 100
$$

where $\mathrm{n}$ is number of diseased plants, $\mathrm{N}-$ total number of plants assessed.

Disease severity index (\%) was calculated using the formula (Лошакова и др., 2000):

$$
\text { DSI }=\frac{\sum(\mathrm{ab}) \times 100}{\mathrm{~A} \times \mathrm{S}},
$$

where $\mathrm{a}$ is number of infected plants of a given rating, $\mathrm{b}$ - rating value, $\mathrm{A}$ - total number of plant samples (healthy and infected), $\mathrm{S}$ - highest rating value.

To combine these repeated observations into a single value the area under the disease progress curve (AUDPC) was calculated by using the formula (Simko, Piepho, 2012):

$$
\text { AUDPC }=\sum_{i=1}^{n-1} \frac{y_{i}+y_{i+1}}{2} \times\left(t_{i+1}-t_{i}\right),
$$

where $\mathrm{n}$ is the total number of observations, $\mathrm{y}_{\mathrm{i}}-$ an assessment of a disease severity index (percentage) at the $\mathrm{i}^{\text {th }}$ observation, $\mathrm{t}_{\mathrm{i}}$ - time (in days) at the $\mathrm{i}^{\text {th }}$ observation.

The AUDPC derived phenotype $(\mathrm{P})$ and overall phenotype (OP) on each flax genotype was evaluated using a modified method of Toffolatti et al. (2012).

To determine the level of a partial (horizontal) resistance, the resistance index (RI) (susceptibility) was calculated using the formula (Кудрявцева и др., 2016):

$$
\mathrm{RI}=\frac{\mathrm{AUDPC}_{\text {genotype }}}{\mathrm{AUDPC}_{\text {standard }}},
$$

where $\mathrm{AUDPC}_{\text {genotype }}$ is area under the disease progress curve of the genotype, AUDPC standard $_{\text {- area }}$ under the disease progress curve of the standard cultivar 'Vega 2'.

Meteorological conditions. Agro-meteorological conditions were determined by ADCON installed meteorological station connected to the system Dacom Plant-Plus (Dacom Plant Service, The Netherlands). In the study, hydrothermal coefficient (HTC) of each month was calculated during the growing season (Fig. 1). The calculations were performed using the formula (Selyaninov, 1928):

$\mathrm{HTC}=\Sigma x / \Sigma t \times 10$,

where $\Sigma x$ is the total precipitation for the period (mm), $\Sigma t-$ the total temperature for the period, in which the average temperature exceeds $10^{\circ} \mathrm{C}$.

Ranges of values of this index were classified according to Selianinov coefficient modified by Skowera et al. (2014) as: extremely dry $-\mathrm{HTC} \leq 0.4$, very dry $0.4<$ HTC $\leq 0.7$, dry $-0.7<\mathrm{HTC} \leq 1.0$, relatively dry $1.0<\mathrm{HTC} \leq 1.3$, optimal $-1.3<\mathrm{HTC} \leq 1.6$, relatively humid $-1.6<\mathrm{HTC} \leq 2.0$, humid $-2.0<\mathrm{HTC} \leq 2.5$, very humid $-2.5<\mathrm{HTC} \leq 3$ and extremely humid $\mathrm{HTC}>3.0$.

The hydrothermal conditions during the growth stages of flax differed (Fig. 1). In 2014, HTC was 1.8 and in 2016 it was 1.9 , relatively humid, in 2015 it was 1.2 relatively dry. However, in 2017 it was 2.7 , very humid with HTC in August being 317\%, which is extremely high compared to the long-term average.

Statistical analysis. Software Excel (Microsoft, USA) was used for data statistical analysis. Significant differences among the measured characteristics of flax were compared by Fisher's protected least significant difference (LSD) tests $(p \leq 0.05)$. The correlation coefficient was used to analyse significant $(p \leq 0.05$ or $p \leq 0.01)$ relationships between HTC and AUDPC for adult plants as well as between HTC during stages $\mathrm{BBCH}$ 81 and BBCH 83 and causal agent incidence (I) for seeds of each genotype by years. Software SPSS Statistics, version 22.0 (IBM Crop., USA) was used for cluster analysis. Cluster analysis was performed to construct a distance matrix using the Euclidean coefficient and based on Ward's method. Cluster analysis was examined for the first dendrogram of different flax genotypes for stem yield as well as for the second seed yield and both included resistance index for each genotype of six diseases. This type of clustering identifies relatively homogeneous groups of cases based on selected characteristics.

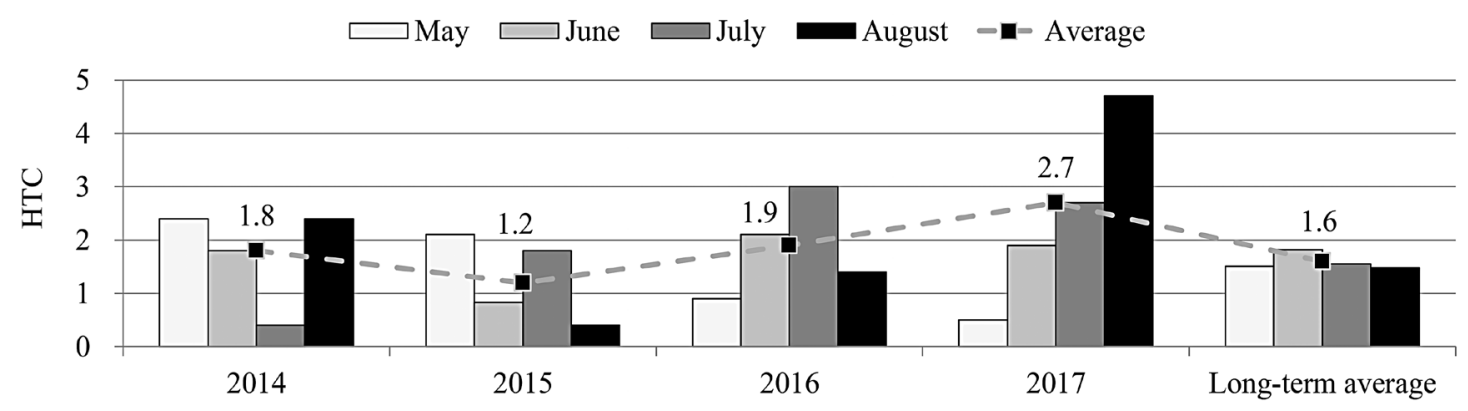

Figure 1. Hydrothermal coefficient (HTC) of each month and average during 2014-2017 growing seasons of flax 
An algorithm is used that starts with cases in a separate cluster and combines clusters until only one is left.

\section{Results and discussion}

In this study, six harmful fungal diseases were identified during the three growing periods on flax accessions: flax wilt, pasmo, anthracnose, powdery mildew, fusarium browning and browning, stem break of flax and their respective pathogens Fusarium oxysporum f. sp. lini, Septoria linicola, Colletotrichum lini, Oidium lini, Fusarium spp. and Polyspora lini. According to the literature, causal agents of those diseases are widespread in the regions, where flax is intensively cultivated (Heller et al., 2015; Wang et al., 2018).

The resistance measures by AUDPC determined for flax population were statistically significantly $(p \leq 0.05)$ dependent on the year of sowing (Fig. 2). Overall, AUDPC was significantly highest $(p \leq 0.05)$ to anthracnose, fusarium browning, the lowest to flax wilt and powdery mildew during the three-year period. Flax accessions showed the significant highest $(p \leq 0.05)$
AUDPC difference to stem break, browning of flax, powdery mildew and lowest - to flax wilt in 2015. AUDPC showed the significantly highest difference to fusarium browning, pasmo and lowest powdery mildew during 2016. AUDPC was the significantly highest $(p \leq 0.05)$ to anthracnose and lowest to fusarium browning in 2017 . Humidity conditions greatly differed between the three years of this study. According to soil analysis, agrochemical indicators did not significantly differ between years, which suggested complex (genetic, environment) factors influencing the growth and development of causal agents and flax. This fact suggests that the flax genotype resistance level to the diseases is affected by changes brought by different hydrothermal conditions of each individual year or occurrence of the disease during vegetation period in a single year leaves longer lasting effect on host populations. A study by Rashid and Kenaschuk (1993) reveals that the flax resistance among cultivars can differ due to the variability of pathogen races in different geographical regions with varying temperatures and environmental conditions.

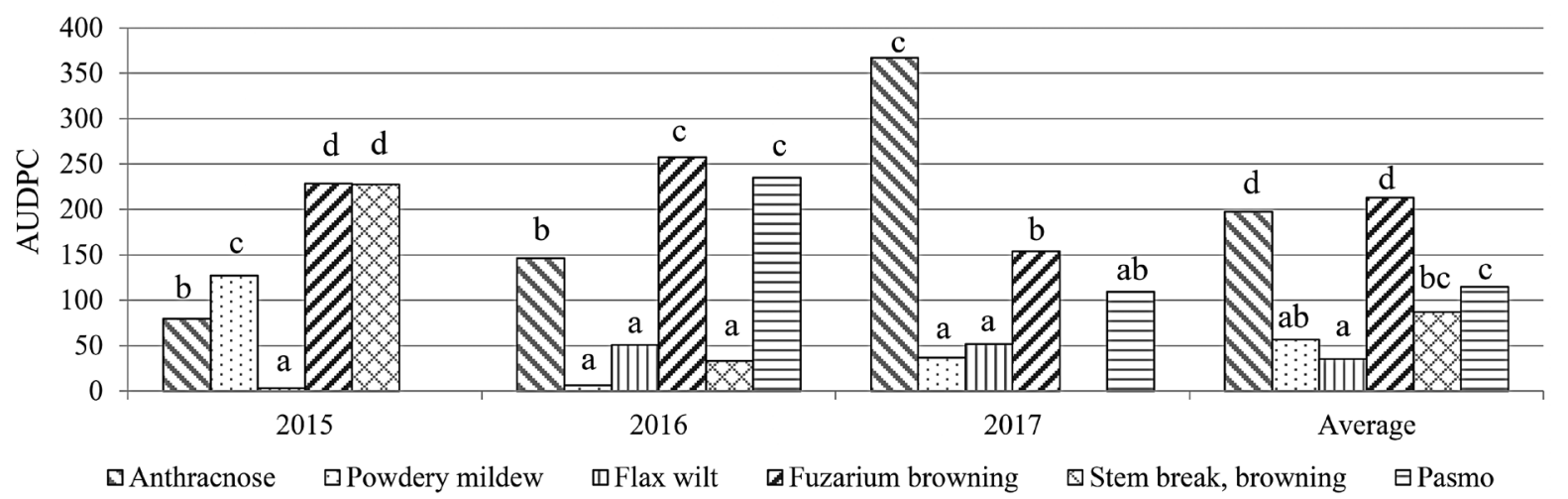

Note. abcd - means followed by the same letters in each column are not statistically significant; $\operatorname{LSD}_{0.05(2015)}=39.36$, $\mathrm{LSD}_{0.05(2016)}=65.24, \mathrm{LSD}_{0.05(2017)}=87.93, \mathrm{LSD}_{0.05(\text { average })}=41.68$.

Figure 2. Values of area under the disease progress curve (AUDPC) of the flax genotypes for different diseases in 2015-2017

Considering each disease, significant differences $(p \leq 0.05)$ among the AUDPC values observed on the different genotypes were found (Tables 2 and 3). Based on statistical analysis, flax genotypes were classified in three different phenotypes: resistant characterized by low AUDPC, susceptible with high AUDPC and intermediate AUDPC. Phenotypically the genotype of S53/8-3-93 (P3) showed the highest resistance to anthracnose, the genotypes 'Rota 2' (P23) and 'Ruda 1' (P24) had the highest resistance to flax wilt and genotypes T25/5-33/128-94 (P7), T36-26/4-8-94 (P11), L26-47/1-97 (P19) and 'Rezeknes' (P21) - to pasmo. A study by Кудрявцева и др. (2016) used a similar method for identifying the horizontal resistance of flax genotypes against pasmo. The availability of flax accessions resistant to flax wilt, anthracnose and pasmo has importance for commercial growers globally. According to Diederichsen et al. (2008) the experiment performed in Canada, where 153 flax accessions from 24 countries were evaluated, showed higher than average resistance to flax wilt, anthracnose and pasmo in accessions from East Asia, while germplasm from the Indian subcontinent showed considerably lower than average resistance; germplasm from North America and South America (mostly linseed) displayed above average resistance to flax wilt, while European accessions (mostly fibre flax) showed lower than average resistance to this disease. A study by Dmitriev et al. (2017) has revealed that the mechanisms of flax response to flax wilt have been actively studied; however, the data on the plant response to infection and resistance gene candidates are currently very limited.

The genotype effect on susceptibility to diseases in different humidity conditions was quite variable between the three years of this study (Tables 2 and 3). The correlation confirmed significant positive relationships between anthracnose, flax wilt AUDPC and level of humidity for the majority of genotypes. The correlation coefficient showed that 6 genotypes to anthracnose and 8 genotypes to flax wilt were more susceptible to these diseases in the growing seasons with high humidity. Muskett (2008) similarly found that flax was more susceptible to anthracnose and flax wilt in the wetter and cooler regions of England. The pasmo development on flax genotypes was identified only in 2016 and 2017. 
Table 2. The values of area under the disease progress curve (AUDPC) and derived phenotype (P) of different flax genotypes with anthracnose, flax wilt and pasmo, and correlation coefficient $(r)$ between HTC and AUDPC for each respective disease and genotype of flax

\begin{tabular}{|c|c|c|c|c|c|c|c|c|c|}
\hline \multirow{2}{*}{ Genotype } & \multicolumn{3}{|c|}{ Anthracnose } & \multicolumn{3}{|c|}{ Flax wilt } & \multicolumn{3}{|c|}{ Pasmo } \\
\hline & AUDPC & $\mathrm{P}$ & $r$ & AUDPC & $\mathrm{P}$ & $r$ & AUDPC & $\mathrm{P}$ & $r$ \\
\hline P1 & $106.56 \mathrm{abcd}$ & I & 0.57 & $29.53 \mathrm{abcd}$ & I & $0.99 * *$ & 188.58 efg & I & 0.88 \\
\hline $\mathrm{P} 2$ & 300.27 efghi & I & 0.75 & $17.90 \mathrm{ab}$ & $\mathrm{R}$ & -0.88 & $175.86 \mathrm{defg}$ & I & 0.31 \\
\hline P3 & $4.69 \mathrm{a}$ & $\mathrm{R}$ & -0.46 & $65.33 \mathrm{fg}$ & I & $0.95^{*}$ & $190.92 \mathrm{fg}$ & $\mathrm{S}$ & 0.75 \\
\hline P4 & $133.74 \mathrm{bcd}$ & I & 0.88 & $21.77 \mathrm{abc}$ & $\mathrm{R}$ & 0.85 & $136.88 \mathrm{bcdefg}$ & I & 0.84 \\
\hline P5 & $336.01 \mathrm{hi}$ & $\mathrm{S}$ & $0.98 *$ & $14.78 \mathrm{ab}$ & $\mathrm{R}$ & 0.55 & 149.34 cdefg & I & 0.09 \\
\hline P6 & $59.86 \mathrm{abc}$ & $\mathrm{R}$ & 0.89 & $25.68 \mathrm{abcd}$ & I & $0.99 * *$ & 77.80 abcde & I & -0.04 \\
\hline P7 & $168.81 \mathrm{~cd}$ & I & 0.92 & $45.92 \mathrm{cdef}$ & I & $0.98 *$ & $17.90 \mathrm{a}$ & $\mathrm{R}$ & -0.04 \\
\hline P8 & $148.58 \mathrm{~cd}$ & I & 0.59 & $56.77 \mathrm{efg}$ & $\mathrm{S}$ & 0.94 & $51.35 \mathrm{abc}$ & $\mathrm{R}$ & -0.04 \\
\hline P9 & 224.81 defghi & I & 0.73 & $42.79 \mathrm{cdef}$ & I & $0.99 * *$ & 142.75 cdefg & I & -0.04 \\
\hline $\mathrm{P} 10$ & $195.21 \mathrm{def}$ & I & 0.92 & $39.66 \mathrm{cde}$ & I & 0.70 & 99.53 abcdef & I & -0.04 \\
\hline P11 & $343.79 \mathrm{i}$ & $\mathrm{S}$ & 0.77 & $27.22 \mathrm{abcd}$ & I & 0.82 & $15.56 \mathrm{a}$ & $\mathrm{R}$ & -0.04 \\
\hline $\mathrm{P} 12$ & 317.39 fghi & I & 0.54 & $49.00 \mathrm{def}$ & I & $0.99 * *$ & $28.78 \mathrm{ab}$ & $\mathrm{R}$ & -0.04 \\
\hline $\mathrm{P} 13$ & 209.96 defg & I & -0.23 & $79.35 \mathrm{~g}$ & $\mathrm{~S}$ & 0.97 & $176.58 \mathrm{defg}$ & I & 0.49 \\
\hline P14 & $194.48 \mathrm{def}$ & I & $0.99 * *$ & $28.78 \mathrm{abcd}$ & I & 0.14 & $74.66 \mathrm{abcd}$ & I & -0.04 \\
\hline $\mathrm{P} 15$ & 275.32 efghi & I & 0.83 & $19.45 \mathrm{ab}$ & $\mathrm{R}$ & 0.72 & $28.80 \mathrm{ab}$ & $\mathrm{R}$ & $0.95^{*}$ \\
\hline P16 & 204.16 defg & I & 0.14 & 37.72 abcde & I & 0.09 & $27.22 \mathrm{ab}$ & $\mathrm{R}$ & -0.04 \\
\hline P17 & 289.33 efghi & I & $0.96^{*}$ & $47.45 \mathrm{def}$ & I & 0.10 & 119.80 abcdef & I & 0.45 \\
\hline P18 & $191.34 \mathrm{de}$ & I & $0.96^{*}$ & 33.45 abcde & I & 0.15 & $112.02 \mathrm{abcdef}$ & I & 0.71 \\
\hline P19 & 325.86 ghi & $\mathrm{S}$ & 0.78 & 39.25 bcde & I & 0,43 & $9.33 \mathrm{a}$ & $\mathrm{R}$ & -0.04 \\
\hline P20 & $21.02 \mathrm{ab}$ & $\mathrm{R}$ & 0.02 & $45.90 \mathrm{cdef}$ & I & 0.80 & $638.56 \mathrm{~h}$ & $\mathrm{~S}$ & $0.99 * *$ \\
\hline $\mathrm{P} 21$ & $60.70 \mathrm{abc}$ & $\mathrm{R}$ & 0.88 & $27.22 \mathrm{abcd}$ & I & 0.88 & $14.00 \mathrm{a}$ & $\mathrm{R}$ & 0.88 \\
\hline $\mathrm{P} 22$ & $203.39 \mathrm{def}$ & I & $0.98 *$ & $21.78 \mathrm{abc}$ & $\mathrm{R}$ & $0.95^{*}$ & 108.87 abcdef & I & -0.04 \\
\hline $\mathrm{P} 23$ & $187.31 \mathrm{de}$ & I & 0.87 & $14.68 \mathrm{a}$ & $\mathrm{R}$ & $0.95^{*}$ & $232.16 \mathrm{~g}$ & $\mathrm{~S}$ & -0.02 \\
\hline P24 & 211.58 defgh & I & 0.89 & $13.23 \mathrm{a}$ & $\mathrm{R}$ & 0.37 & $26.44 \mathrm{ab}$ & $\mathrm{R}$ & 0.12 \\
\hline $\mathrm{P} 25$ & 227.94 defghi & $\mathrm{I}$ & $0.98 *$ & 35.00 abcde & $\mathrm{I}$ & -0.04 & $26.45 \mathrm{ab}$ & $\mathrm{R}$ & -0.04 \\
\hline $\mathrm{LSD}_{0.05}$ & 124.64 & & & 24.82 & & & 111.4 & & \\
\hline
\end{tabular}

Note. The genotype phenotype (P) is classified as susceptible (S), intermediate (I) or resistant (R); a-i means followed by the same letters in each column are not statistically significant; ${ }^{*}$ - correlation significant at $p \leq 0.05,{ }^{*}-$ at $p \leq 0.01$.

The correlation confirmed significant positive progress of pasmo on the genotypes L11-11/10-97 (P15) and 'Altgauzen' (P20) in the growing seasons with high humidity. Rashid et al. (2003), Perryman et al. (2009) and Hall et al. (2016) have revealed a similar conclusion that flax is most susceptible to pasmo under moist conditions.

In this study, one flax genotype 'Rezeknes' (P21) with complete resistance and 16 genotypes with significantly low susceptibility to powdery mildew were identified (Table 3). As reported by Rashid and Duguid (2005), in classical genetic studies several cultivars: 'AC Watson', 'AC McDuff' and 'AC Emerson' from Canada as well 'Atalante' and 'Linda' from Europe, were resistant to powdery mildew. In this study, most promising genotypes with the highest resistance level S13/5-7/5-93 (P1), S64-17-93 (P4), T11-6/2-15-94 (P5) and T25/533/12-8-94 (P7) to fusarium browning, and L23-26/3-97 (P18) and L26-47/1-97 (P19) to stem break, browning were identified. The resistance of the flax accessions to both diseases in the world have not been well studied.

The correlation confirmed significant negative relationships between powdery mildew, stem break, browning AUDPC and level of humidity for the majority of genotypes. The correlation coefficient shows that in the dry growing season genotypes T29-36/10-5-94 (P8) and T31-40-94 (P10) were more susceptible to stem break, browning, and genotype L23-26/3-97 (P18) - to powdery mildew (Table 3). The results confirmed significant negative relationships between fusarium browning and level of humidity for the majority of genotypes. The genotypes T11-13/3-1-94 (P6), T29-36/7-1-94 (P9), L23-26/3-97 (P18), 'Rota 1' (P22) and 'Ruda 1' (P24) were more susceptible to fusarium browning in the dry growing season, but the genotypes S53/8-3-93 (P3), T31-40-94 (P10) and L11-11/11-97 (P16) showed susceptibility in the growing season with high humidity. Additional studies should be carried out on flax genotypes in order to obtain a clear picture about their resistance to various causal agents of Fusarium spp. Overall, in most of the cases the flax genotypes phenotypically showed intermediate-resistant or variable susceptibility (Table 3 ). This study identified 12 flax genotypes with intermediateresistance that are more useful for further research and one K47-17/11-6-95 (P12) genotype with intermediatesusceptibility to all diseases, which is not recommended in plant breeding as resistant to diseases.

In this study, of all the genotypes tested only one genotype 'Rezeknes' (P21) was identified with complete resistance to the powdery mildew and the lowest susceptibility to pasmo and anthracnose as well as relatively low susceptibility to other diseases except fusarium browning.

According to Wang et al. (2018), overall, one of the main breeding aims of fibre flax is the highest 
Table 3. The values of area under the disease progress curve (AUDPC) and derived phenotype (P) of different flax genotypes with powdery mildew, fusarium browning and stem break, browning, and correlation coefficient $(r)$ between HTC and AUDPC for each respective disease and genotype of flax

\begin{tabular}{|c|c|c|c|c|c|c|c|c|c|c|}
\hline \multirow{2}{*}{ Genotype } & \multicolumn{3}{|c|}{ Powdery mildew } & \multicolumn{3}{|c|}{ Fusarium browning } & \multicolumn{3}{|c|}{ Stem break, browning } & \multirow{2}{*}{$\mathrm{OP}$} \\
\hline & AUDPC & $\mathrm{P}$ & $r$ & AUDPC & $\mathrm{P}$ & $r$ & AUDPC & $\mathrm{P}$ & $r$ & \\
\hline P1 & $21.77 \mathrm{a}$ & $\mathrm{R}$ & -0.85 & $122.93 \mathrm{a}$ & $\mathrm{R}$ & -0.71 & $73.11 \mathrm{abc}$ & $\mathrm{I}$ & -0.85 & IR \\
\hline $\mathrm{P} 2$ & $39.68 \mathrm{a}$ & $\mathrm{R}$ & -0.85 & $240.36 \mathrm{def}$ & I & -0.16 & $112.67 \mathrm{abc}$ & I & -0.86 & IR \\
\hline P3 & $56.77 \mathrm{ab}$ & I & -0.85 & $160.97 \mathrm{abc}$ & I & $0.97 *$ & $81.67 \mathrm{abc}$ & I & -0.85 & $\mathrm{~V}$ \\
\hline P4 & $63.78 \mathrm{ab}$ & I & -0.91 & $136.16 \mathrm{a}$ & $\mathrm{R}$ & -0.76 & $119.12 \mathrm{bc}$ & I & -0.86 & IR \\
\hline P5 & $39.67 \mathrm{a}$ & $\mathrm{R}$ & -0.85 & $144.67 \mathrm{a}$ & $\mathrm{R}$ & -0.78 & $95.67 \mathrm{abc}$ & I & -0.85 & $\mathrm{~V}$ \\
\hline P6 & $51.34 \mathrm{a}$ & $\mathrm{R}$ & -0.91 & $189.82 \mathrm{abcd}$ & I & $-0.99 * *$ & $84.00 \mathrm{abc}$ & I & -0.85 & IR \\
\hline P7 & $43.53 \mathrm{a}$ & $\mathrm{R}$ & -0.97 & $142.34 \mathrm{a}$ & $\mathrm{R}$ & -0.16 & $126.03 \mathrm{bc}$ & I & -0.81 & IR \\
\hline P8 & $63.78 \mathrm{ab}$ & I & -0.85 & $286.22 \mathrm{f}$ & $\mathrm{S}$ & -0.04 & $100.00 \mathrm{abc}$ & I & $-0.99 * *$ & $\mathrm{~V}$ \\
\hline P9 & $39.67 \mathrm{a}$ & $\mathrm{R}$ & -0.85 & $410.25 \mathrm{~h}$ & $\mathrm{~S}$ & $-0.99 * *$ & $60.67 \mathrm{abc}$ & I & -0.86 & $\mathrm{~V}$ \\
\hline P10 & $45.90 \mathrm{a}$ & $\mathrm{R}$ & -0.85 & $152.42 \mathrm{ab}$ & $\mathrm{R}$ & $0.99 * *$ & $136.90 \mathrm{c}$ & $\mathrm{S}$ & $-0.99 * *$ & $\mathrm{~V}$ \\
\hline P11 & $120.56 \mathrm{c}$ & I & -0.22 & $243.45 \mathrm{~d}$ & I & -0.79 & $113.34 \mathrm{abc}$ & I & -0.94 & $\mathrm{~V}$ \\
\hline P12 & $182.77 \mathrm{~d}$ & $\mathrm{~S}$ & 0.49 & 280.77 ef & I & -0.69 & $123.63 \mathrm{bc}$ & I & -0.81 & V \\
\hline P13 & $127.57 \mathrm{c}$ & I & 0.32 & $190.56 \mathrm{bcd}$ & I & -0.33 & $78.56 \mathrm{abc}$ & I & -0.85 & IS \\
\hline P14 & $105.80 \mathrm{bc}$ & I & 0.19 & $252.87 \mathrm{de}$ & I & -0.48 & $82.55 \mathrm{abc}$ & I & -0.85 & I \\
\hline P15 & $65.32 \mathrm{ab}$ & I & -0.85 & $156.31 \mathrm{ab}$ & $\mathrm{R}$ & -0.75 & $66.89 \mathrm{abc}$ & I & -0.85 & IR \\
\hline P16 & $48.99 \mathrm{a}$ & $\mathrm{R}$ & -0.85 & $214.70 \mathrm{bcde}$ & I & $0.99 * *$ & $58.11 \mathrm{ab}$ & $\mathrm{R}$ & -0.85 & IR \\
\hline P17 & $33.44 \mathrm{a}$ & $\mathrm{R}$ & -0.85 & $159.52 \mathrm{abc}$ & I & -0.46 & $46.67 \mathrm{ab}$ & $\mathrm{R}$ & -0.85 & IR \\
\hline P18 & $29.95 \mathrm{a}$ & $\mathrm{R}$ & $-0.98^{*}$ & $184.36 \mathrm{abc}$ & I & $-0.99 * *$ & $38.66 \mathrm{a}$ & $\mathrm{R}$ & -0.85 & IR \\
\hline P19 & $23.35 \mathrm{a}$ & $\mathrm{R}$ & -0.85 & $217.81 \mathrm{bcde}$ & I & 0.65 & $35.77 \mathrm{a}$ & $\mathrm{R}$ & -0.85 & V \\
\hline P20 & $45.09 \mathrm{a}$ & $\mathrm{R}$ & -0.85 & $225.60 \mathrm{cdef}$ & I & -0.54 & $82.77 \mathrm{abc}$ & I & -0.85 & V \\
\hline P21 & 0 & $\mathrm{R}$ & 0 & $355.85 \mathrm{gh}$ & $\mathrm{S}$ & 0.14 & $94.12 \mathrm{abc}$ & I & -0.86 & V \\
\hline P22 & $41.22 \mathrm{a}$ & $\mathrm{R}$ & -0.85 & $266.06 \mathrm{ef}$ & I & $-0.97^{*}$ & $103.90 \mathrm{abc}$ & I & -0.85 & IR \\
\hline P23 & $32.66 \mathrm{a}$ & $\mathrm{R}$ & -0.85 & $165.67 \mathrm{abc}$ & I & -0.91 & $74.33 \mathrm{abc}$ & I & -0.85 & V \\
\hline P24 & $40.45 \mathrm{a}$ & $\mathrm{R}$ & -0.85 & $263.67 \mathrm{ef}$ & I & $-0.95^{*}$ & $91.34 \mathrm{abc}$ & I & -0.85 & IR \\
\hline $\mathrm{P} 25$ & $53.66 \mathrm{a}$ & $\mathrm{R}$ & -0.92 & $167.23 \mathrm{abc}$ & $\mathrm{I}$ & -0.94 & $90.56 \mathrm{abc}$ & I & -0.85 & IR \\
\hline $\mathrm{LSD}_{0.05}$ & 49.23 & & & 67.14 & & & 78.36 & & & \\
\hline
\end{tabular}

Note. The genotype phenotype (P) is classified as susceptible (S), intermediate (I) or resistant (R); overall phenotypes (OP) of each genotype to all diseases are intermediate-susceptible (IS), intermediate (I), intermediate-resistant (IR) or variable from susceptible to resistant $(\mathrm{V})$; a-f means followed by the same letters in each column are not statistically significant; * - correlation significant at $p \leq 0.05, * *-$ at $p \leq 0.01$.

yield potential and complex resistance to diseases. In this study, complex disease resistance and flax genotypes' productivity were evaluated to understand the resistance difference between the tested genotypes. The dendrogram was developed by a cluster analysis on the basis of resistance index of six evaluated fungal diseases, stem yield (Fig. 3) and seed yield (Fig. 4). According to the flax stem yield, the genotypes diverged in two main groups - the first group included genotypes with statistically highest and the second - with the lowest stem yield (Fig. 3). The main group of the first cluster was divided into two sub-groups within the range 15 to 20 as a threshold. The first sub-cluster included five genotypes with statistically highest stem yield and intermediate-resistance to diseases, and second subcluster included 16 genotypes with medium yield and relative high susceptibility to different diseases. The first dendrogram of the second main group included four different genotypes with low stem yield and variable susceptibility to some diseases.

According to the seed yield of flax, the genotypes diverged in two main cluster groups (Fig. 4). The first group included eight genotypes with statistically highest

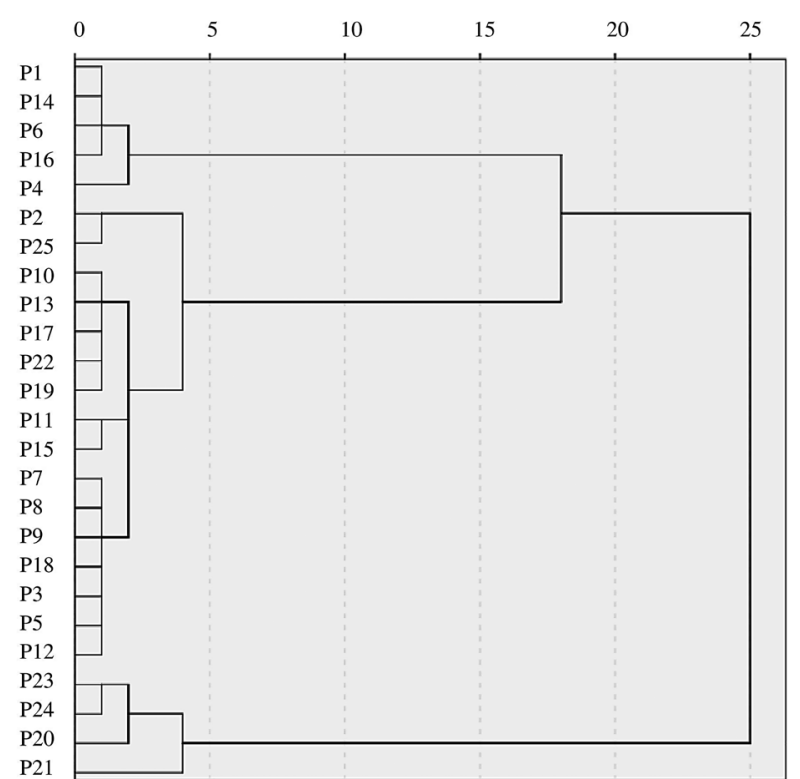

Figure 3. Dendrogram based on the genotypes of flax stem yield and resistance index for six diseases 


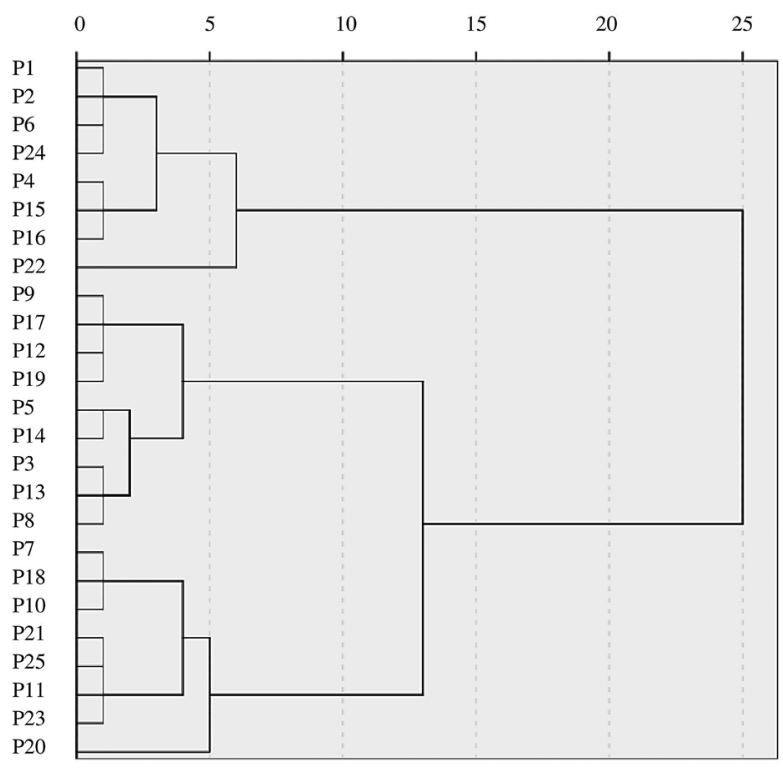

Figure 4. Dendrogram based on the genotypes of flax seed yield and resistance index for six diseases seed yield and intermediate-resistance to diseases. The second main group cluster was divided into two subgroups with a threshold within the range 10 to 15 . The first sub-group cluster incorporated nine genotypes with statistically medium seed yield, and the second sub-group cluster incorporated the rest seven genotypes with low yield, and with both sub-group clusters having relatively high susceptibility to diseases.

In both dendrograms, the first sub-clusters under the first main cluster indicated good potential for the breeding program. Consequently, it is a suitable group for producing the highest stem and seed yield as well as low susceptibility to all diseases compared with the standard cultivar 'Vega 2' (P25). To summarize, the most promising flax genotypes from all identified were S13/5-7/5-93 (P1), S64-17-93 (P4), T11-13/3-1-94 (P6) and L11-11/11-97 (P16) with the highest productivity and high complex resistance.

There were identified two causal agents Colletotrichum lini and Fusarium spp. as the most prevalent affecting of flax seeds genotypes (Table 4).

The genetic response of flax seeds to Fusarium spp. was statistically significantly different $(p \leq 0.05)$

Table 4. Fusarium spp. and Colletotrichum lini incidence (I, \%) on the flax genotypes, and correlation coefficient ( $r$ ) between HTC and incidence for each disease causal agent and genotype of flax at the seedling stage

\begin{tabular}{|c|c|c|c|c|c|c|c|c|}
\hline \multirow{2}{*}{ Genotype } & \multicolumn{4}{|c|}{ Fusarium spp. } & \multicolumn{4}{|c|}{ Colletotrichum lini } \\
\hline & $I_{\min }$ & $I_{\max }$ & $I_{\text {average }}$ & $r$ & $I_{\min }$ & $\mathrm{I}_{\max }$ & $I_{\text {average }}$ & $r$ \\
\hline $\mathrm{P} 1$ & 4.0 & 16.0 & 9.0 bcdef & 0.77 & 0.0 & 16.0 & $4.0 \mathrm{abcd}$ & 0.87 \\
\hline $\mathrm{P} 2$ & 0.0 & 18.0 & 8.5 bcde & 0.47 & 0.0 & 28.0 & $13.0 \mathrm{i}$ & 0.59 \\
\hline $\mathrm{P} 3$ & 0.0 & 25.0 & $16.9 \mathrm{hi}$ & 0.13 & 0.0 & 4.0 & $2.0 \mathrm{a}$ & 0.86 \\
\hline P4 & 0.0 & 4. 0 & $1.0 \mathrm{a}$ & -0.68 & 0.0 & 20.0 & 5.0 abcdef & 0.87 \\
\hline P5 & 0.0 & 8.0 & $5.5 \mathrm{abcd}$ & -0.04 & 0.0 & 21.0 & 9.3 efghi & 0.63 \\
\hline P6 & 0.0 & 16.0 & 8.5 bcde & -0.30 & 0.0 & 10.0 & $3.5 \mathrm{abc}$ & 0.64 \\
\hline P7 & 0.0 & 50.0 & $25.0 \mathrm{j}$ & 0.00 & 0.0 & 6.0 & $3.0 \mathrm{ab}$ & 0.51 \\
\hline P8 & 0.0 & 35.0 & $19.5 \mathrm{ij}$ & 0.82 & 0.0 & 12.0 & 4.5 abcde & 0.68 \\
\hline P9 & 0.0 & 10.0 & 7.0 bcde & 0.19 & 0.0 & 16.0 & 8.0 cdefgh & 0.51 \\
\hline $\mathrm{P} 10$ & 4.0 & 18.0 & 9.5 cdef & 0.03 & 0.0 & 16.0 & $4.0 \mathrm{abcd}$ & 0.87 \\
\hline P11 & 0.0 & 4.0 & $1.0 \mathrm{a}$ & -0.68 & 0.0 & 25.0 & $11.3 \mathrm{hi}$ & 0.61 \\
\hline $\mathrm{P} 12$ & 0.0 & 10.0 & $4.0 \mathrm{ab}$ & 0.48 & 0.0 & 30.0 & 10.0 ghi & 0.94 \\
\hline $\mathrm{P} 13$ & 0.0 & 20.0 & 8.5 bcde & -0.21 & 0.0 & 8.0 & $2.0 \mathrm{a}$ & 0.87 \\
\hline P14 & 0.0 & 10.0 & $4.0 \mathrm{ab}$ & -0.77 & 4.0 & 9.0 & 5.8 abcdefg & 0.64 \\
\hline P15 & 8.0 & 10.0 & 8.5 dcde & 0.41 & 0.0 & 40.0 & $13.5 \mathrm{i}$ & 0.80 \\
\hline $\mathrm{P} 16$ & 0.0 & 18.0 & $4.5 \mathrm{abc}$ & -0.68 & 0.0 & 25.0 & 8.8 defgh & $0.97 *$ \\
\hline $\mathrm{P} 17$ & 0.0 & 6.0 & $1.5 \mathrm{a}$ & -0.68 & 0.0 & 16.0 & 8.0 cdefgh & 0.46 \\
\hline P18 & 0.0 & 20.0 & $12.0 \mathrm{efgh}$ & -0.51 & 0.0 & 20.0 & 9.5 fghi & $0.98^{*}$ \\
\hline P19 & 0.0 & 32.0 & 15.0 ghi & 0.70 & 6.0 & 12.0 & 8.0 cdefgh & 0.82 \\
\hline $\mathrm{P} 20$ & 0.0 & 42.0 & 14.3 fghi & 0.93 & 0.0 & 20.0 & 7.5 bcdefgh & $0.97 *$ \\
\hline $\mathrm{P} 21$ & 0.0 & 0.0 & 0.0 & 0.00 & 0.0 & 12.0 & $3.5 \mathrm{abc}$ & 0.93 \\
\hline $\mathrm{P} 22$ & 0.0 & 18.0 & 10.8 efg & 0.45 & 2.0 & 15.0 & 8.3 cdefgh & 0.55 \\
\hline $\mathrm{P} 23$ & 0.0 & 10.0 & $5.5 \mathrm{abcd}$ & 0.56 & 2.0 & 12.0 & 5.5 abcdefg & 0.76 \\
\hline $\mathrm{P} 24$ & 2.0 & 30.0 & $10.0 \mathrm{defg}$ & $0.98 *$ & 2.0 & 10.0 & 6.5 abcdefgh & 0.25 \\
\hline $\mathrm{P} 25$ & 0.0 & 10.0 & $4.5 \mathrm{abc}$ & -0.38 & 2.0 & 12.0 & 7.0 bcdefgh & 0.41 \\
\hline $\mathrm{LSD}_{0.05}$ & & & 5.4 & & & & 4.8 & \\
\hline
\end{tabular}

Note. a-i means followed by the same letters in each column are not statistically significant; ${ }^{*}$ - correlation significant at $p \leq 0.05$, $* *$ - at $p \leq 0.01$. 
during the four-year period. Assessment of the flax genetic response to Fusarium spp. identified the most susceptible genotype T25/5-33/2-8-94 (P7) $(\mathrm{I}=25 \%)$ with the highest rate of $50 \%$. Only one genotype of 'Rezeknes' (P21) has complete resistance and the lowest incidence rates of S64-17-93 (P4) (1\%), T36-26/4-8-94 (P11) (1\%) and L19-6/15-97 (P17) (2\%) for the seeds during the four-year period. The contamination of the seeds by the fungus Fusarium spp. significantly impacted seed germination and development. The infected germs were identified as small and crippled compared to uninfected or completely non-germinated.

The statistically significant differences $(p \leq 0.05)$ of genotype susceptibility response to Colletotrichum lini for the flax seeds were found. The $C$. lini is the causal agent of anthracnose that intensively spreads to flax seeds and can affect seed germination and plant development during the vegetation period. The average highest incidence was shown of L11-11/10-97 (P15) (I=13.5\%) with highest rate of $40 \%$. The most valuable genotypes with the lowest incidence K47-17/11-6-95 (P13) (2\%), S53/8-3-93 (P3) (2\%), T25/5-33/12-8-94 (P7) (3\%) and 'Rezeknes' (P21) (3.5\%) were identified. The secondary infection of flax seeds is the basis for the distribution of anthracnose in flax fields.

The effects of weather conditions on the secondary infection of the seeds were observed (Table 4). The hydrothermal conditions have a significant impact on the pathogens spreading on the seeds of flax genotypes: during the $\mathrm{BBCH} 81$ and $\mathrm{BBCH} 83$ stages in years with the highest humidity the quantity of propagules of $C$. lini and Fusarium spp. on seeds increased. The correlation confirmed significant positive relationships between spreading of Fusarium spp. and level of humidity. A study by Gruzdevienè et al. (2006) obtained similar results in Lithuania. The significant correlation coefficient shows that the incidence of secondary infection of Fusarium spp. on seeds of genotype 'Ruda 1' (P24) was the highest in high humidity conditions during the ripening period. However, some of the researched genotypes showed tendencies to be susceptible to Fusarium spp. in the dry growing season. Regarding the susceptibility of different genotypes to Fusarium spp., the response is unclear and additional research is needed. The correlation confirmed positive relationship for the majority of genotypes between spreading of $C$. lini and level of humidity.

The significant correlation coefficient shows that the incidences of secondary infections of $C$. lini on seeds of genotypes L11-11/11-97 (P16), L23-26/3-97 (P18) and 'Altgauzen' (P20) were the highest in high humidity conditions during the early ripening period. Results indicated that the most valuable genotype was T25/5-33/12-8-94 (P7) that had the smallest coefficient $(r=0.51)$ and the highest resistance to secondary infection of $C$. lini in humid conditions when the seeds were formed.

\section{Conclusions}

1. Intermediate resistance to diseases and the highest yields were identified for flax genotypes S13/57/5-93 (P1), S64-17-93 (P4), T11-13/3-1-94 (P6) and L11-11/11-97 (P16), while the genotype 'Rezeknes'
(P21) exhibited complete resistance to the powdery mildew. The genotypes are most valuable and could be used for flax breeding.

2. The study found that Latvian flax genetic resources population has different resistance levels to the six flax diseases tested. During the three growing seasons the lowest resistance was identified to fusarium browning and the highest resistance to flax wilt.

3. The study proved additionally that flax resistance to different diseases was significantly influenced by the hydrothermal conditions in the years of sowing and the genotypes. Flax genotypes were more susceptible to fusarium browning, stem break, browning of flax and powdery mildew in the growing season with drier conditions and to pasmo, anthracnose and flax wilt in the growing season with high humidity.

4. The genotype 'Rezeknes' (P21) exhibited high resistance to the causal agents Fusarium spp. and Colletotrichum lini at the seedling stage. The highest susceptibility to both causal agents on the flax seeds was identified in high humidity conditions during the early ripening period.

Received 13112018 Accepted 25082019

\section{References}

1. Agarwal V. K., James B. 1996. Sinclair principles of seed pathology $\left(2^{\text {nd }}\right.$ ed.). CRC Press, $560 \mathrm{p}$.

2. Belonogova M., Radulgina G. 2007. Biotechnology of flax (Linum usitatissimum). Functional Plant Science and Biotechnology, 1 (2): 327-346.

3. Damm U., O'Connell R. J., Groenewald J. Z., Crous P. W. 2014. The Colletotrichum destructivum species complex hemibiotrophic pathogens of forage and field crops. Studies in Mycology, 79: 49-84.

https://doi.org/10.1016/j.simyco.2014.09.003

4. Diederichsen A., Rozhimina R. A., Kudrjavceva L. P. 2008. Variation patterns within 153 flax (Linum usitatissimum L.) genebank accessions based on evaluation for resistance to fusarium wilt, anthracnose and pasmo. Plant Genetic Resources: Characterization and Utilization, 6: 22-32. https://doi.org/10.1017/S1479262108913897

5. Dmitriev A. A., Krasnov G. S, Rozhmina T. A., Novakovskiy R. O., Snezhkina A. V., Fedorova M. S., Yurkevich O. Y., Muravenko O. V., Bolsheva N. L., Kudryavtseva A. V., Melnikova N. V. 2017. Differential gene expression in response to Fusarium oxysporum infection in resistant and susceptible genotypes of flax (Linum usitatissimum L.). BMC Plant Biology, 17 (2): 253. https://doi.org/10.1186/s12870-017-1192-2

6. Dunford N. T. 2015. Hemp and flaxseed oil: properties and applications for use in food. Specialty oils and fats in food and nutrition ( $1^{\text {st }}$ ed.). Cambridge, UK, p. 39-63.

https://doi.org/10.1016/B978-1-78242-376-8.00002-8

7. Finch H. J. S., Samuel A. M., Lane G. P. F. 2014. Lockhart and Wiseman's crop husbandry including grassland ( $9^{\text {th }}$ ed.). Woodhead Publishing, UK, p. 263-283. https://doi.org/10.1016/C2013-0-23267-0

8. Galindo-Gonzalez L., Deyholos M. K. 2016. RNA-seq transcriptome response of flax (Linum usitatissimum L.) to the pathogenic fungus Fusarium oxysporum f. sp. lini. Frontiers in Plant Science, 7: 1766. https://doi.org/10.3389/fpls.2016.01766 
9. Grimault V., Serandat I., Brochard C., Kohen R., Brière S. 2014. 7-007: detection of Alternaria linicola, Botrytis cinerea and Colletotrichum lini on Linum usitatissimum (flax) seed. International Rules for Seed Testing Annexe to Chapter 7: Seed Health Testing Methods.

10. Gruzdevienè E., Mankevičienė A., Lugauskas A., Repečkienè J. 2006. The effect of environmental conditions on the variation of fungi and mycotoxin contents in oil flax seed. Ekologija, 3: 64-70.

11. Gudmewad R. B., Khandagale S. G., Kumara S. R. V. 2016. Correlation and path coefficient analysis of economically important traits in linseed (Linum usitatissimum L.) germplasm. Electronic Journal of Plant Breeding, 7 (2): 427-433. https://doi.org/10.5958/0975-928X.2016.00053.3

12. Hall L. M., Booker H., Siloto R. M. P., Jhala A. J., Weselake R. J. 2016. Flax (Linum usitatissimum L.). Mc Keon T. A. et al. (eds). Industrial oil crops. American Oil Chemists' Society Press, p. 157-194. https://doi.org/10.1016/B978-1-893997-98-1.00006-3

13. Heller K., Sheng Q. C., Guan F., Alexopoulou E., Hua L. S., Wu G. W., Jankauskiene Z., Fu W. Y. 2015. A comparative study between Europe and China in crop management of two types of flax: linseed and fibre flax. Industrial Crops and Products, 68: 24-31.

https://doi.org/10.1016/j.indcrop.2014.07.010

14. Jankauskienè Z., Gruzdevienè E. 2008. Resistant cultivar - a biological way to control flax fungal diseases. Zemdirbyste-Agriculture, 95 (3): 312-319.

15. Loshakova N. I. 1992. Flax breeding for disease resistance in the Soviet Union. Sharma H. S. S., Van Sumere C. F. (eds). The biology and processing of flax. Belfast, Northern Ireland, p. 67-71.

16. Mankeviciene A., Suproniene S., Brazauskiene I., Gruzdeviene E. 2011. Natural occurrence of Fusarium mycotoxins in oil crop seed. Plant Breeding and Seed Science, 63: 109-116. https://doi.org/10.2478/v10129-011-0022-1

17. Malone J. P., Muskett A. E. 1997. Seed-borne fungi. Description of 77 fungus species. ( $3^{\text {rd }}$ ed.). International Seed Testing Association, Zürich, Switzerland, $191 \mathrm{p}$.

18. Muskett A. E. 2008. Studies on seed health. Annals of Applied Biology, 46 (3): 430-445.

https://doi.org/10.1111/j.1744-7348.1958.tb02224.x

19. Nozkova J., Brindza J., Stehlikova B., Pavelek M. 2006. Importance of collected flax germplasm (Linum usitatissimum L.): characterization. Journal of Natural Fibres, 3 (1): 1-16. https://doi.org/10.1300/J395v03n01_01

20. Nozkova J., Pavelek M., Bjelkova M., Brutch N., Tejklova E., Porokhovinova E., Brindza J. 2016. Descriptor list for flax (Linums usitatissimum L.). Slovak University of Agriculture in Nitra, p. 92-94. https://doi.org/10.15414/2016.9788055214849

21. Penaud A., Paumier D., Bamme B., Petiteau A., Héritier E., Suffert F., Valade R. 2017. Epidemiology of pasmo and assessment of Septoria linicola resistance in French flax cultivars. 12 $2^{\text {th }}$ European Foundation for Plant Pathology and $10^{\text {th }}$ French Society for Plant Pathology Conference. Malo-les-Bains, France. https://www.researchgate.net/ publication $/ 317647361$

22. Perryman S. A. M., Gladders P., Fitt B. D. L. 2009. Autumn sowing increases severity of pasmo (Mycosphaerella linicola) on linseed in the UK. Annals of Applied Biology, 154: 19-32.

https://doi.org/10.1111/j.1744-7348.2008.00271.x
23. Rachinskaya O. A., Lemesh V. A., Muravenko O. V., Yurkevich O. Yu., Guzenko E. V., Bol'sheva N. L. Bogdanova M. V., Samatadze T. E., Popov K. V., Malyshev S. V., Shostak N. G., Heller K., Hotyleva L. V., Zelenin A. V. 2011. Genetic polymorphism of flax Linum usitatissimum based on the use of molecular cytogenetic markers, Genetika, 47 (1): 65-75. https://doi.org/10.1134/S1022795411010108

24. Rashid K. Y., Kenaschuk E. O. 1993. Effect of trifluralin on fusarium wilt in flax. Canadian Journal of Plant Science, 73: 893-901. https://doi.org/10.4141/cjps93-117

25. Rashid K., Duguid S. 2005. Inheritance of resistance to powdery mildew in flax. Canadian Journal Plant Pathology, 27 (3): 404-409. https://doi.org/10.1080/07060660509507239

26. Rashid K. Y., Bailey K. L., Gossen B. D., Gugel R. K., Morrall R. A. A. 2003. Diseases of flax. Diseases of field crops in Canada ( $3^{\text {rd }}$ ed.). Saskatoon, Canada, p. 147-154.

27. Selyaninov G. L. 1928. O sel'skogo khozyaistvennoi otsenka klimata. Trudy VNIGMI, 20: 177-185 (in Russian).

28. Simko I., Piepho H. P. 2012. The area under the disease progress stairs: calculation. Advantage, and Application Phytopathology, 102 (4): 381-389. https://doi.org/10.1094/PHYTO-07-11-0216

29. Skowera B., Jędrszczyk E., Kopcińska J., Ambroszczyk A. M., Kolton A. 2014. The effects of hydrothermal conditions during vegetation period on fruit quality of processing tomatoes. Polish Journal of Environmental Studies, 23 (1): 195-202.

30. Toffolatti S. L., Venturini G., Maffi D., Vercesi A. 2012. Phenotypic and histochemical traits of the interaction between Plasmopara viticola and resistant or susceptible grapevine varieties. BMC Plant Biology, 12: 124. https://doi.org/10.1186/1471-2229-12-124

31. Van Inghelandt D., Melchinger A. E., Lebreton C., Stich B. 2010. Population structure and genetic diversity in a commercial maize breeding program assessed with SSR and SNP markers. Theoretical and Applied Genetics, 120 (7): 1289-1299.

https://doi.org/10.1007/s00122-009-1256-2

32. Wang Y. F., Jankauskiene Z., Qiu C. S., Gruzdeviene E., Long S. H., Alexopoulou E., Guo Y., Szopa J., Hao D. M., Fernando A. L., Wang H. 2018. Fiber flax breeding in China and Europe. Journal of Natural Fibers, 15 (3): 309-324. https://doi.org/10.1080/15440478.2017.1325431

33. Wojtasik W., Kulma A., Namys K., Preisner M., Szopa J. 2015. Polyamine metabolism in flax in response to treatment with pathogenic and non-pathogenic Fusarium strains. Frontiers in Plant Science, 6: 291. https://doi.org/10.3389/fpls.2015.00291

34. WRB. 2014. World reference database for soil resources. World soil resources report No. 106. FAO, p. 187-189.

35. You F. M., Jia G., Xiao J., Duguid S. D., Rashid K. Y., Booker H. M., Cloutier S. 2017. Genetic variability of 27 traits in a core collection of flax (Linum usitatissimum L.). Frontiers in Plant Science, 8: 1636. https://doi.org/10.3389/fpls.2017.0163

36. Карпунин Б. Ф. 2015. Антракноз льна. Селекция на устойчивость: монография. Москва, 160 с. (in Russian).

37. Кудрявцева Л. П., Павлова Л. Н., Рожмина Т. А. 2016. Исходный материал для селекции льна на горизонтальную устойчивость к септориозу (пасмо). Инновационные разработки производства и переработки лубяных культур: материалы международной научно-практической конференции. Тверь, 318 с. (in Russian).

38. Лошакова Н. И., Крылова Т. В., Кудрявцева Л. П. 2000. Методические указания по фитопатологической оценке устойчивости льна-долгунца к болезням. Москва, 52 с. (in Russian). 
ISSN 1392-3196 / e-ISSN 2335-8947

Zemdirbyste-Agriculture, vol. 106, No. 4 (2019), p. 367-376

DOI 10.13080/z-a.2019.106.047

\title{
Sẻjamojo lino genotipụ atsparumas ligoms, priklausomai nuo aplinkos veiksnių
}

\author{
I. Stafecka ${ }^{1,2}$, D. Grauda ${ }^{3}$, V. Stramkale ${ }^{1}$ \\ 'Priekulès tyrimų centro Žemès ūkio išteklių ir ekonomikos institutas, Latvija \\ ${ }^{2}$ Daugpilio universitetas, Latvija \\ ${ }^{3}$ Latvijos universiteto Biologijos institutas
}

\section{Santrauka}

Grybinès ligos yra vienas iš sejjamojo lino (Linum usitatissimum L.) augimą ribojančių veiksnių, juos auginant kintančio klimato sąlygomis. Grybinių ligų plitimas priklauso nuo augalų atsparumo, patogenų populiacijos gebos įveikti ši atsparumą ir augalų augimo sąlygų. Tyrimo metu siekta ịvertinti sẻjamojo lino atsparumą grybinėms ligoms lauko sąlygomis, atsižvelgiant ị aplinkos veiksnius, ir nustatyti pačius perspektyviausius genotipus selekcijai. Buvo tirti 24 vietinès kilmès genotipai. Sejjamojo lino genotipai, turintys nevienodą atsparumą dažniausiai pasitaikančioms ligoms, buvo nustatyti naudojant ligos pažeisto lapų ploto indeksą (AUDPC) ir atsparumo indeksą: didelès drègmès sąlygomis buvo tirtas jautrumas linų fuzarioziniam vytuliui (sukèlèjas Fusarium oxysporum f. sp. lini), pasmai (sukèlèjas Septoria linicola) ir antraknozei (sukèlèjas Colletotrichum lini), sausesnèmis sąlygomis tirtas jautrumas stiebalūžei (sukèlejjas Polyspora lini), miltligei (sukèlèjas Oidium lini) ir fuzariozei (arba fuzarioziniam parudavimui) (sukèlèjas Fusarium spp.). Ligų sukèlèjų Fusarium spp. ir C. lini didžiausias paplitimas ant linų sẻklų buvo nustatytas esant didelei drègmei. Patys vertingiausi sejjamojo lino genotipai S13/5-7/5-93, S64-17-93, T11-13/3-1-94 ir L11-11/11-97 buvo kompleksiškai atsparūs ligoms ir davė didesnị derlių nei standartinè veislė 'Vega 2'. Genotipas 'Rezekne' pasižymėjo didesniu atsparumu miltligei daigų ir visišku atsparumu suaugusio augalo tarpsniais.

Reikšminiai žodžiai: jautrumas, ligos sukèlèjai, Linum usitatissimum, selekcija. 